\title{
Frequency of Anti-HCV, HBsAg, HIV1-p24 Antigen, Acid Fast Bacilli and Plasmodium spp., in Herbal Home and Hospital Patients with Elevated TNF $\alpha(\geq 5.0 \mathrm{pg} / \mathrm{ml})$ in Saki, West Nigeria
}

\author{
Mathew Folaranmi Olaniyan ${ }^{1 *}$ (D) and Mufutau M. Azeez ${ }^{2}$ \\ ${ }^{1}$ Department of Medical Laboratory Science, Edo University lyamho, Nigeria. ${ }^{2}$ Department of Medical Laboratory \\ Science, Leads City University, Ibadan, Nigeria.
}

\begin{abstract}
Infectious agents and chemical substances can trigger the production and the release of cytokines. To determine the pattern of infectious agents in herbal homes patients with elevated TNF $\alpha(\geq 5.0$ $\mathrm{pg} / \mathrm{ml})$ in Saki - West-Nigeria. The subjects include patients with elevated TNF $\alpha(\geq 5.0 \mathrm{pg} / \mathrm{ml})$ in 15 herbal homes $(n=23$; aged 5-69 years; males -13 ; females -10$)$ and patients with elevated TNF $\alpha$ in 3 major hospitals ( $n=32$; aged 6 -67years; males - 12 ; females - 20). Plasma TNF $\alpha$, anti-HCV, HBsAg and HIV1-p24 antigen were determined by ELISA, Plasmodium spp., by Giemsa thick film staining and Acid Fast Bacilli by Ziehl-Nelson staining. The frequency of infectious agents obtained in the patients include $4.3 \%(1)$ anti-HCV; 17.4\% (4) HBsAg; $4.3 \%$ (1) HIV1-p24 antigen; 17.4\% (4) Plasmodium spp.; 8.7 \%(2) Acid Fast Bacilli and $4.3 \%(1) \mathrm{HBsAg}+$ Plasmodium spp., in patients of herbal homes and 6.3 \%(2) anti-HCV; 9.4\% (3) HBsAg; $3.1 \%(1)$ HIV1-p24 antigen; 15.6\% (6)Plasmodium spp., 0\%(0) Acid Fast Bacilli and $3.1 \%(1) \mathrm{HBsAg}+$ Plasmodium spp., in patients of the three major hospitals. The frequency of those with $5.0-6,0 \mathrm{pg} / \mathrm{ml} \mathrm{TNF} \alpha(65.2 \%$ (15)) was more than those whose TNF $\alpha$ was between 6.1 $6.8 \mathrm{pg} / \mathrm{ml}(34.8 \%(8)$ in herbal home patients while the frequency of those with $5.0-6,0 \mathrm{pg} / \mathrm{ml} \mathrm{TNF} \alpha$ (40.6\%(13)) was lower than those whose TNF $\alpha$ was between $6.1-6.8 \mathrm{pg} / \mathrm{ml}(59.4 \%(19))$ in hospital patients. The pattern of the infectious agents was more in herbal home patients with $5.0-6,0 \mathrm{pg} /$ $\mathrm{ml} \mathrm{TNF} \alpha$ than those with $6.1-6,8 \mathrm{pg} / \mathrm{ml}$ TNF $\alpha$ while in hospital patients it was more in those with $6.1-6,8 \mathrm{pg} / \mathrm{ml}$ TNF $\alpha$ than those with $5.0-6,0 \mathrm{pg} / \mathrm{ml}$ TNF $\alpha$. The overall frequency of the infectious agents was more in herbal homes patients $(58.5 \%(13))$ than $37.5 \%(12)$ obtained in hospital patients. The frequency of viral immunochemical biomarkers, Acid Fast Bacilli and Plasmodium spp., was more in herbal home patients than the patients recruited from the hospital which varies with the TNF $\alpha$ range.

Keywords: Anti-HCV, HBsAg, HIV1-p24 antigen, Acid Fast Bacilli, Plasmodium spp., herbal homes patients, elevated TNF $\alpha$.
\end{abstract}

\footnotetext{
*Correspondence: olaniyanmat@gmail.com; +2348052248019
}

(Received: 17 January 2019; accepted: 02 March 2019)

Citation: Mathew Folaranmi Olaniyan and Mufutau M. Azeez, Frequency of Anti-HCV, HBsAg, HIV1-p24 Antigen, Acid Fast Bacilli and Plasmodium spp., in Herbal Home And Hospital Patients With Elevated TNF $\alpha(\geq 5.0 \mathrm{pg} / \mathrm{ml})$ in Saki, West Nigeria, J Pure Appl Microbiol., 2019; 13(2): 841-846. doi: 10.22207/JPAM.13.2.19

(c) The Author(s) 2019. Open Access. This article is distributed under the terms of the Creative Commons Attribution 4.0 International License which permits unrestricted use, sharing, distribution, and reproduction in any medium, provided you give appropriate credit to the original author(s) and the source, provide a link to the Creative Commons license, and indicate if changes were made. 


\section{INTRODUCTION}

Herbal treatment involves the administration of dietary supplement in form of tablets, capsules, powders, teas, extracts, and fresh or dried plants. People believe the treatment is safe and natural. Plants are basis for medical treatments in human history. Pharmaceutical drugs are made from many plant-derived compounds. According to World Health Organization (WHO) about 80 percent of the population in Asian and African countries use herbal medicine for some aspect of primary health care ${ }^{1,2}$. About $25 \%$ of modern drugs used in the United States were derived from plants ${ }^{1,2}$. At least 7,000 medical compounds in the modern pharmacopoeia are derived from plants. Out of the 120 active compounds currently isolated from plants and used in modern medicine currently, $80 \%$ show a positive correlation between their modern therapeutic use and the traditional use of the plants from which they are derived ${ }^{1,2}$.

Herbal treatment is more prevalent in patients with cancer, diabetes, asthma, viral infection, Plasmodiasis, hypertension/hypercholesterolemia and end-stage renal disease. Multiple factors such as gender, age, ethnicity, education and social class are also shown to have association with prevalence of herbal remedies use $^{1-4}$. The most common administration of herbs in treatment in Nigeria is through drinking of raw liquid extract or aqueous extract through boiling ${ }^{5}$. Herbal treatment can cause adverse effects due to possible adulteration, inappropriate formulation, administration or lack of understanding of plant and drug interactions $s^{6,7}$.

The practice of herbalism entails that herbalists must learn wild-crafting, cultivation of herbs, diagnosis and treatment of ailments, preparations and dispensing of herbal medications ${ }^{8}$. Non-hygeinic and unethical practices by some herbalists could bring about cross infection and contaminations during product preparation ${ }^{8,9}$

Tumor necrosis factor (TNF $\alpha$ ) is one of the cell signaling proteins known as cytokine involved in systemic inflammation; It is a cytokine that make up the acute phase reaction. It is produced by activated macrophages, CD4+ lymphocytes, NK cells, neutrophils, mast cells, eosinophils, endothelial cells, cardiac myocytes, adipose tissue, fibroblasts and neurons. It acts as an endogenous pyrogen, it induces fever, apoptotic cell death, cachexia, inflammation, inhibits tumorigenesis and viral replication ${ }^{10,11}$.

It acts on organ and system as proinflammatory cytokine to stimulate the release of corticotropin releasing hormone (CRH), suppressing appetite, induce fever, stimulate acute phase response which causes increase in C-reactive protein, stimulates phagocytosis, regulates bitter taste perception ${ }^{12,13}$. A local increase in concentration of TNF will brings about signs of Inflammation such as : heat, swelling, redness, pain and loss of function. The synthesis and release of TNF $\alpha$ are trigger by presence of infectious agents and chemicals that result in inflammation especially hepatitis ${ }^{12,13}$.

Inappropriate use of herbs, some phytochemicals, phytonutrients and infectious agents can induce inflammation ${ }^{12,13}$. This work was therefore designed to determine the Viral immunochemical frequency of anti-HCV, $\mathrm{HBsAg}$ and HIV1-p24 antigen including pattern of other infectious agents in herbal homes patients with elevated TNF $\alpha(\geq 5.0 \mathrm{pg} / \mathrm{ml})$ in Saki - West-Nigeria

\section{MATERIALS AND METHODS \\ Study area}

The study area is Saki-West local government area at the Northern part of Oyo state in Nigeria. It is a semi-urban area that shares border with Burkina faso, Kwara state, Saki-East and ATISBO local government areas in Nigeria. Many of its Inhabitants practice herbal medicine personally or by visiting herbal homes. It hosts 244 Racee battalion of Nigeria army, Baptist School of Nursing, School of Medical Laboratory Technology, Muslim Hospital School of Basic Midwifery, The Oke-Ogun Polytechnic, Baptist Medical Centre, Oyo State Hospital, Muslim Hospital and Oyo state Technical College.

\section{Study population}

This include patients with elevated $\operatorname{TNF} \alpha(\geq 5.0 \mathrm{pg} / \mathrm{ml})$ who volunteered themselves in 15 herbal homes $(n=23$; aged $5-69$ years; males -13 ; females -10 ) and also patients with elevated TNF $\alpha$ who volunteered in 3 major hospitals $(n=$ 32; aged $6-67$ years; males -12 ; females - 20) in Saki-West local government area of Oyo state Nigeria. 


\section{Biological specimens}

Five milliliters of venous blood was collected into lithium heparinized specimen bottle to determine viral biomarkers and plasma TNF $\alpha$. Sputum was also obtained from each of the patients for the demonstration of Acid Fast Bacilli.

\section{Methods}

\section{TNF alpha ELISA}

Plasma TNF alpha was determined in the subjects using Abcam's kit. Abcam's

A monoclonal antibody specific TNF alpha has been coated onto the wells of the microtiter strips provided. Samples, including standards of known TNF alpha concentrations, control specimens or unknowns are pipetted into these wells. During the first incubation, the standards or samples and a biotinylated monoclonal antibody specific for TNF alpha are simultaneously incubated. After washing, the enzyme StreptavidinHRP, that binds the biotinylated antibody is added, incubated and washed. A TMB substrate solution is added which acts on the bound enzyme to induce a colored reaction product. The intensity of this colored product is directly proportional to the concentration of TNF alpha present in the samples. HIV-1 p24 Antigen ELISA using Zeptrometrix retrotek kit

Principle

Microwells are coated with a monoclonal antibody specific for the p24 gag gene product of HIV-1. Viral antigen in the specimen is specifically captured onto the immobilized antibody during specimen incubation. The captured antigen is then reacted with a high tittered human antiHIV-1 antibody conjugated with biotin. Following a subsequent incubation with StreptavidinPeroxidase, color develops as the bound enzyme reacts with the substrate. Resultant optical density is proportional to the amount of HIV-1 p24 antigen present in the specimen.

\section{Anti HCV ELISA Assay}

This was determined by using AntiHepatitis C Virus Core Antigen antibody (ab50288) Abcam kit.

\section{HBsAg ELISA Test}

This was assayed using Diagnostic automation/ Cortez Diagnostics, INC kit by ELISA method

Principle

The HBsAg ELISA Test kit employs an

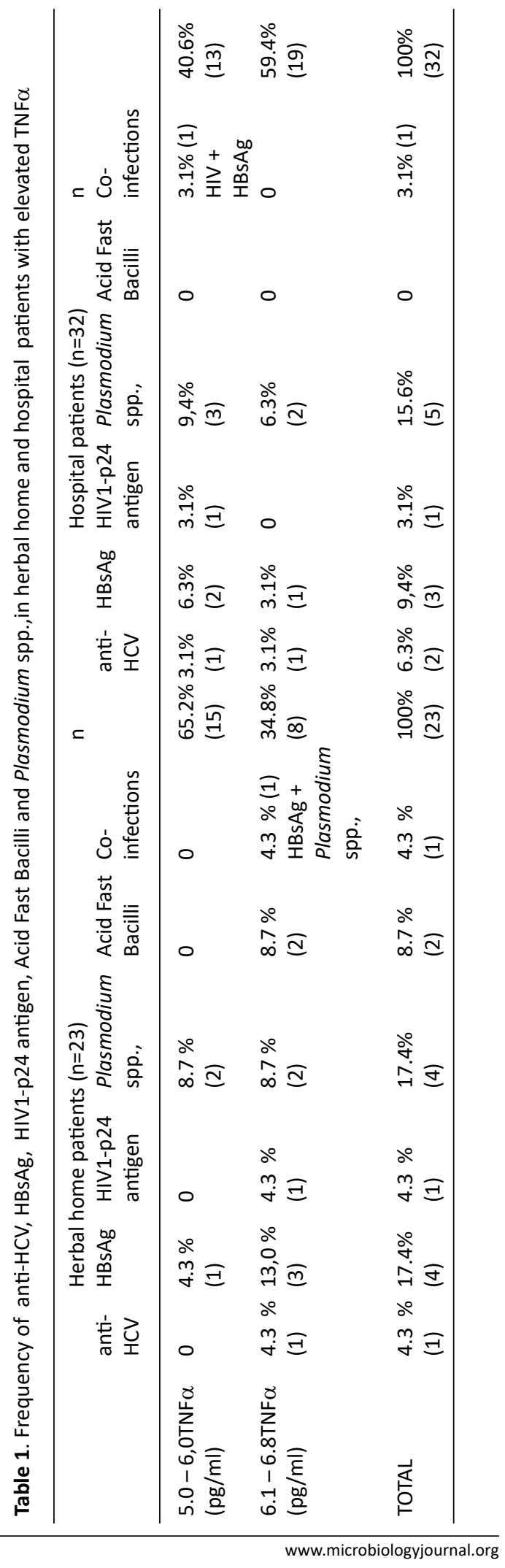


antibody sandwich ELISA technique where monoclonal antibodies unique to $\mathrm{HBsAg}$, are pre-coated on polystyrene microwell strips. The plasma sample was added together with a second After incubation and washing, to eliminate unwanted serum proteins and unbound HRP-conjugate, chromogen solutions containing tetramethyl-benzidine (TMB) and urea peroxide were added to the wells. The colorless chromogens were hydrolyzed by the bound HRP-conjugate to a blue-colored product. Sulfuric acid was added to stop the reaction and the blue color then turns yellow. This color intensity is directly proportional to the amount of antigen in the samples. If the blue colour remains colorless it indicates $\mathrm{HBsAg}$ negative.

\section{Demonstration of Acid Fast Bacilli in sputum}

Ziehl-Neelsen ( $\mathrm{Zn}$ ) staining technique was used to demonstrate Acid Fast Bacilli (Mycobacterium sp) as Described by Cheesbrough ${ }^{14}$. Identification of Plasmodium species Giemsa staining-thick blood film technique

Plasmodium species were determined by Giemsa staining-thick blood film technique as described by Cheesbrough ${ }^{14}$.

\section{Ethical Consideration}

Ethical approval for this work was obtained from ethical and research committee of Baptist Medical center Saki-Nigeria before the commencement of this work. Informed consent was also obtained from each of the patients.

Methods of Data Analysis

Data were analysed for mean, percentage and frequency using Statistical Package for Social Sciences (IBM SPSS, version 18).

\section{RESULTS}

The overall frequency of the infectious agents was more in herbal homes patients $(58.5 \%(13))$ than $37.5 \%(12)$ obtained in hospital patients.

The viral immunochemical frequency of anti-HCV, HBsAg and HIV1-p24 antigen including pattern of other infectious agents in herbal homes patients with elevated TNF $\alpha$ ( $\geq 5.0 \mathrm{pg} /$ $\mathrm{ml}$ ) include $4.3 \%(1)$ anti-HCV; $17.4 \%$ (4) HBsAg; $4.3 \%(1)$ HIV1-p24 antigen; $17.4 \%$ (4) Plasmodium spp.; $8.7 \%(2)$ Acid Fast Bacilli and 4.3\%(1) HBsAg + Plasmodium spp., in patients of herbal homes and $6.3 \%(2)$ anti-HCV; 9.4\% (3)HBsAg; $3.1 \%(1)$ HIV1-p24 antigen; $15.6 \%$ (6) Plasmodium spp.,; 0\%(0) Acid Fast Bacilli and 3.1\%(1) HBsAg + Plasmodium spp., in patients of the three major hospitals (Table 1 ).

The frequency of those with $5.0-6.0 \mathrm{pg} /$ $\mathrm{mlTNF} \alpha(65.2 \%(15))$ was more than those whose TNF $\alpha$ was between $6.1-6.8 \mathrm{pg} / \mathrm{ml}(34.8 \%(8))$ in the results obtained in herbal home patients while the frequency of those with $5.0-6.0 \mathrm{pg} / \mathrm{ml} \mathrm{TNF} \alpha$ (40.6\%(13)) was lower than those whose TNF $\alpha$ was between $6.1-6.8 \mathrm{pg} / \mathrm{ml}(59.4 \%(19))$ in the results obtained in hospital patients(Table 1 ).

The pattern of the infectious agents was more in hospital patients with $5.0-6.0 \mathrm{pg} / \mathrm{ml}$ TNF $\alpha$ than those with $6.1-6.8 \mathrm{pg} / \mathrm{ml}$ TNF $\alpha$ while the pattern of the infectious agents was more in hospital patients with $6.1-6.8 \mathrm{pg} / \mathrm{ml}$ TNF $\alpha$ than those with $5.0-6.0 \mathrm{pg} / \mathrm{ml}$ TNF $\alpha$ (Table 1).

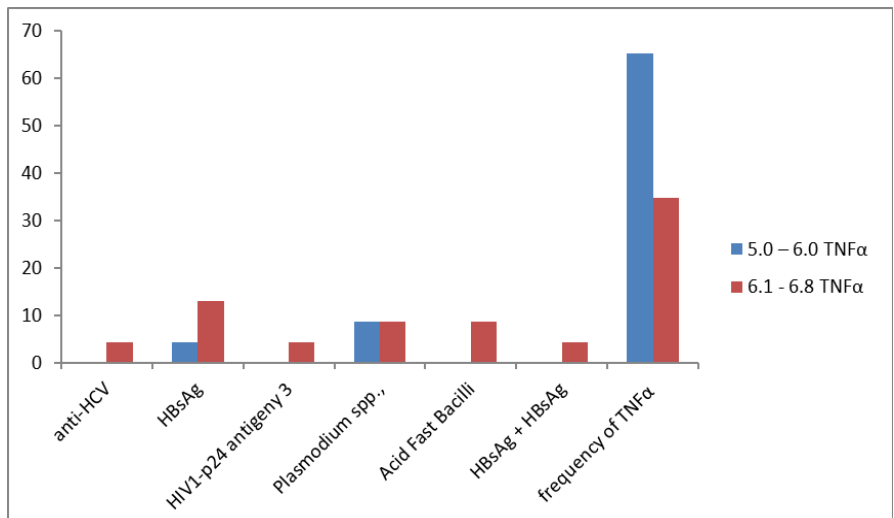

Fig. 1. Frequency of anti-HCV, HBsAg, HIV1-p24 antigen, Acid Fast Bacilli and Plasmodium spp., in herbal home patients 


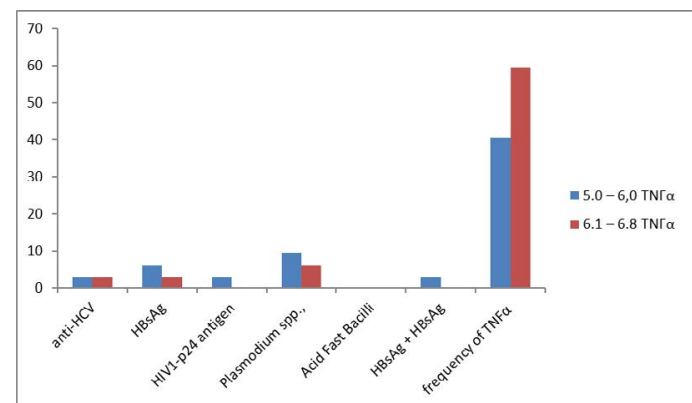

Fig. 2. Frequency of anti-HCV, HBsAg, HIV1-p24 antigen, Acid Fast Bacilli and Plasmodium spp., in hospital patients

\section{DISCUSSION}

The overall frequency of the infectious agents was more in herbal homes patients $(58.5 \%(13))$ than $37.5 \%(12)$ obtained in hospital patients.

The viral immunochemical frequency of anti-HCV, HBsAg and HIV1-p24 antigen including pattern of other infectious agents in herbal homes patients with elevated TNF $\alpha(\geq 5.0 \mathrm{pg} /$ $\mathrm{ml}$ ) include $4.3 \%(1)$ anti-HCV; $17.4 \%$ (4) HBsAg; 4.3 \%(1) HIV1-p24 antigen; $17.4 \%$ (4) Plasmodium spp.; $8.7 \%(2)$ Acid Fast Bacilli and $4.3 \%(1)$ $\mathrm{HBsAg}+$ Plasmodium spp., in patients of herbal homes and $6.3 \%(2)$ anti-HCV; 9.4\% (3) HBsAg; 3.1\%(1) HIV1-p24 antigen; $15.6 \%$ (6) Plasmodium spp.; $0 \%(0)$ Acid Fast Bacilli and 3.1\%(1) HBsAg + Plasmodium spp., in patients of the three major hospitals.

The presence of infectious agents in patients with elevated TNF $\alpha(\geq 5.0 \mathrm{pg} / \mathrm{ml})$ could be attribute to the fact that TNF $\alpha$ is a proinflammatory cytokine. The release is triggered by the presence of infectious agents to initiate process of inflammatory response and inhibit viral replication. It is also involved in acute phase reaction which can be caused by pathogenic agents.

The frequency of those with $5.0-6.0 \mathrm{pg} /$ $\mathrm{mITNF} \alpha(65.2 \%(15))$ was more than those whose TNF $\alpha$ was between $6.1-6.8 \mathrm{pg} / \mathrm{ml}(34.8 \%(8))$ in the results obtained in herbal home patients while the frequency of those with $5.0-6,0 \mathrm{pg} / \mathrm{ml} \mathrm{TNF} \alpha$ (40.6\%(13)) was lower than those whose TNF $\alpha$ was between $6.1-6.8 \mathrm{pg} / \mathrm{ml}(59.4 \%(19))$ in the results obtained in hospital patients.

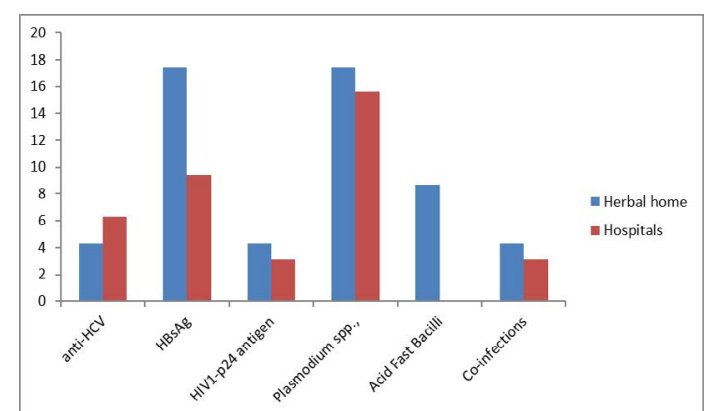

Fig. 3. Comparative analysis of anti-HCV, $\mathrm{HBsAg}$, HIV1-p24 antigen, Acid Fast Bacilli and Plasmodium spp., in herbal home and hospital patients

In addition the pattern of the infectious agents was more in hospital patients with $5.0-$ $6,0 \mathrm{pg} / \mathrm{ml}$ TNF $\alpha$ than those with $6.1-6,8 \mathrm{pg} / \mathrm{ml}$ TNF $\alpha$ while the pattern of the infectious agents was more in hospital patients with $6.1-6,8 \mathrm{pg} /$ $\mathrm{ml} \mathrm{TNF} \alpha$ than those with $5.0-6,0 \mathrm{pg} / \mathrm{ml} \mathrm{TNF} \alpha$.

The explanation to these include the fact that the patients of herbal homes are regular set of individuals who have been accessing herbal treatment for sometimes while those recruited in the hospitals have never received any herbal treatment. This might be responsible for the differences in the frequency as un-hygienic and unethical practices by some herbalists could bring about cross infection and contaminations during product preparation and adminis-tration ${ }^{8,9}$.

This could be due to the following reasons that drugs administered in hospitals apart from infectious agents can trigger inflammatory response leading to increase in plasma TNF $\alpha$ while most herbal preparations contain antiinflammatory and antioxidative agents ${ }^{1,2}$ which may also account for the above results.

The findings of this work is consistent with the report of Yusa ${ }^{15}$ that IL-4, IL-8, IL-10, IL-12 and TNF- $\alpha$ in addition to WBC counts and CRP levels could be a possible biomarkers of infections.

\section{CONCLUSION}

The frequency of viral immunochemical biomarkers, Acid Fast Bacilli and Plasmodium spp., was more in herbal home patients than the patients recruited from the hospital which varies with the TNF $\alpha$ range. 


\section{ACKNOWLEDGMENT}

We would like to express our heartfelt thanks to Herbal home practitioners and their patients in Saki-West local government area Nigeria for providing assistance on sampling.

\section{CONFLICT OF INTERESTS}

The authors declare that there is no conflict of interest.

\section{AUTHORS' CONTRIBUTIONS}

$M O$ and $M A$ conceived and designed the study. MO and MA performed the experiments and analyzed the data. MO and MA wrote the manuscript.

\section{FUNDING}

None.

\section{DATA AVAILABILITY}

All datasets generated or analyzed during this study are included in the manuscript.

\section{ETHICS STATEMENT}

Ethical approval and patients 'consent were obtained before the commencement of the work. Ethical approval was obtained from Research and Ethical Committee of Baptist Medical Centre, Saki - Nigeria.

\section{REFERENCES}

1. US National Institutes of Health. "Clini-caltrials.gov, a registry of studies on herbal medicine". Clinicaltrials. gov,. Retrieved 25 February 2017.

2. Lack, Caleb W.; Rousseau, Jacques. Critical Thinking, Science, and Pseudoscience: Why We Can't Trust Our Brains. Springer Publishing Company. 2016 : pp. 212-214. ISBN 978082-6194268.

3. Fabricant DS, Farnsworth NR. "The value of plants used in traditional medicine for drug discovery". Environ. Health Perspect, 2001; 109(Suppl 1): 69-75. doi:10.1289/ehp.01109s169. PMC 1240543. PMID 11250806.

4. Edgar J. DaSilva; Elias Baydoun; Adnan Badran. "Biotechnology and the developing world". Electronic Journal of Biotechnology, 2002; 5(1). doi:10.2225/ vol5-issue1-fulltext-1. ISSN 0717-3458.

5. Saad, Bashar \& Said, Omar. Greco-Arab and Islamic Herbal Medicine: Traditional System, Ethics, Safety, Efficacy, and Regulatory Issues. John Wiley \& Sons.
2011; p. 80. ISBN 9780470474211.

6. Elvin-Lewis M. "Should we be concerned about herbal remedies". Journal of Ethnopharmacology, 2001; 75(2-3): 141-64. doi:10.1016/S0378-8741 (00)003949. PMID 11297844.

7. Talalay, P; Talalay, P. "The importance of using scientific principles in the development of medicinal agents from plants". Academic Medicine, 2001; 76(3): 238-47. doi:10.1097/00001888-200103000-00010. PMID 11242573.

8. Lin, V.; McCabe, P.; Bensoussan, A.; Myers, S.; Cohen, M.; Hill, S.; Howse, G.. "The practice and regulatory requirements of naturopathy and western herbal medicine in Australia". Risk Management and Healthcare Policy, 2009; 2: 21-33. doi:10.2147/RMHP. S4652. PMC 3270908. PMID 22312205.

9. Coghlan, ML; Haile, J; Houston, J; Murray, DC; White, NE; Moolhuijzen, P; Bellgard, MI; Bunce, M . "Deep Sequencing of Plant and Animal DNA Contained within Traditional Chinese Medicines Reveals Legality Issues and Health Safety Concerns". PLoS Genetics, 2012; 8(4): e1002657. doi:10.1371/journal.pgen.1002657. PMC 3325194. PMID 22511890.

10. Swardfager W, Lanctgt K, Rothenburg L, Wong A, Cappell J, Herrmann N. "A meta-analysis of cytokines in Alzheimer's disease". Biol Psychiatry, 2010; 68(10): 930-941. doi:10.1016/j.biopsych. 2010.06.012. PMID 20692646.

11. Locksley RM, Killeen N, Lenardo MJ . "The TNF and TNF receptor superfamilies: integrating mammalian biology". Cell, 2001; 104(4): 487-501. doi:10.1016/ S0092-8674(01)00237-9. PMID 11239407.

12. Feng P, Jyotaki M, Kim A, Chai J, Simon N, Zhou M, Bachmanov AA, Huang $L$, Wang $H$. "Regulation of bitter taste responses by tumor necrosis factor". Brain, Behavior, and Immunity, 2015; 49: 32-42. doi:10.1016/j.bbi.2015.04.001. PMC 4567432. PMID 25911043.

13. Said EA, Dupuy FP, Trautmann L, Zhang Y, Shi Y, ElFar M, Hill BJ, Noto A, Ancuta P, Peretz Y, Fonseca SG, Van Grevenynghe J, Boulassel MR, Bruneau J, Shoukry NH, Routy JP, Douek DC, Haddad EK, Sekaly RP. "Programmed death-1-induced interleukin-10 production by monocytes impairs CD4+ T cell activation during HIV infection". Nat. Med., 2010; 16(4): 452-9. doi:10.1038/nm.2106. PMC 4229134. PMID 20208540.

14. Cheesbrough Monica. District Laboratory Practice in Tropical Countries Part 2; Second Edition, Published in the United States of America by Cambridge University Press, New York, 2006 www.cambridge. org/9780521676311

15. Yusa T, Tateda K, Ohara A, Miyazaki S. New possible biomarkers for diagnosis of infections and diagnostic distinction between bacterial and viral infections in children. J Infect Chemother, 2017; 23(2):96-100. doi: 10.1016/j.jiac. 2016.11. 002. Epub 2016 Nov 25. 